Amasya Ilahiyat Dergisi - Amasya Theology Journal

ISSN 2667-7326 | e-ISSN 2667-6710

Aralık / December 2020, 15: 179-204

\title{
Oyun, Oyuncak ve Oyuncak Müzelerinin Çocuk Eğitiminde Aktif Olarak Kullanılması ve Başarıya Katkısı
}

\author{
Mustafa ÖNDER \\ Doç. Dr., Cumhuriyet Üniversitesi, Eğitim Fakültesi, \\ Eğitimin Felsefi, Sosyal ve Tarihi Temelleri Anabilim Dalı \\ Associate Professor, Cumhuriyet University, Faculty of Education, \\ Department of the Philosophical, Social and Historical \\ Foundations of Education \\ Sivas, Turkey \\ monder@cumhuriyet.edu.tr \\ orcid.org/0000-0002-9624-0716
}

\section{Makale Bilgisi / Article Information}

Makale Türü / Article Types: Araştırma Makalesi / Research Article

Geliş Tarihi / Received: 30 Temmuz / July 2020

Kabul Tarihi / Accepted: 17 Eylül / September 2020

Yayın Tarihi / Published: 30 Aralık / December 2020

Yayın Sezonu / Pub. Date Season: Aralık / December

Sayı / Issue: 15 Sayfa / Pages: 179-204

Atıf / Cite as: Önder, Mustafa. “Oyun, Oyuncak ve Oyuncak Müzelerinin Çocuk Eğitiminde Aktif Olarak Kullanılması ve Başarıya Katkısı [Active Use of Games, Toys and Toy Museums in Children's Education and Their Contribution to Success]". Amasya Illahiyat Dergisi-Amasya Theology Journal 15 (December 2020): 179-204.

https://doi.org/10.18498/amailad.776044.

Intihal / Plagiarism: Bu makale, en az iki hakem tarafından incelendi ve intihal içermediği teyit edildi. / This article has been reviewed by at least two referees and scanned via a plagiarism software.

Copyright (C Published by Amasya Üniversitesi, İlahiyat Fakültesi / Amasya University, Faculty of Theology, Amasya, 05100 Turkey. All rights reserved. https://dergipark.org.tr/amailad. 
180 I M. ÖNDER / Oyun, Oyuncak ve Oyuncak Müzelerinin Çocuk Eğitiminde Aktif Olarak Kullanılması ve Başarıya Katkısı

\section{Active Use of Games, Toys and Toy Museums in Children's Education and Their Contribution to Success}

\section{Abstract}

Games, toys and toy museums are indispensable elements of modern education. In developed countries and recently in Turkey, it is seen that games, toys and toy museums are effectively used in education and training in all kinds of educational system. It is even known that there is a serious contribution of games and toys in the teaching of religion and morality. Experts describe the game as follows: it is a part of real life and the most effective learning process for the child, the basis of cognitive, physical, emotional, linguistic and social development that is performed willingly and lovingly by children and performed with or without a specific purpose. If it should be noted that this description mentions an action which contributes to the development of the child and performs willingly and lovingly.

A toy is the most important friend and confidant of a child in life. Children learn to control themselves through play and obeying the rules. They play games and conduct various experiments in the game in order to learn and understand what they cannot do in real life. All children have a playmate in their dreams from an early age. These friends usually consist of one or several toys. The games and toys are not only an endeavor and educational activity for young children but also an important activity that contributes to the development of mental health. It is known that the play and toy play activities are likely to be found in children (autism, learning difficulties, etc.) provides an important opportunity for early diagnosis and treatment. These toys can be used for digital addiction, which keeps it up to date and seeks ways to protect children from harm.

In addition to the relationship of games and toys with different branches of science, it also has a close relationship with culture. In Turkey and the World, the important cities are now competing not only with their cultural and historical heritage, tourism movements, but also with educational places focused on games and toys for children. The games and toys are an indicator of the educational systems of countries, but also the common language of all children. The games and toys are very important materials that contain the codes of a country's future vision. It clearly seems that one of the main reasons for the development is the production of toys if we look at the situation of countries 50 or 70 years ago. The toys that Japan produced at that time were 
robots and their derivatives. Today, Japan is unbeatable in robot technology. During the same periods, toys produced by the United States weighed spacecraft and rockets. Today, the United States is also at the forefront of space technology. It is an indicator of creativity about the future that is the production of toys. For this reason, it is an area that should be emphasized by adults.

One of the most important goals of education is to educate generations who have gained understanding, questioning, innovative ideas and the ability to compete with production. The basic condition of acquiring these features is to bring our children together with the games and toys. The countries solved the educational problem in the world have been able to integrate formal education with games, toys and toy museums. The well-known cities that are the focus of attention today are not only those with historical and tourist riches; but they are also cities with rich infrastructure for children.

Toy museums are a complementary element of formal educational institutions, where toys stand out its educational aspect rather than its visuals. In addition to their contribution to children's education, these places will contribute to the emergence of national culture with the domestic toy industry. These institutions can be an incentive for traditional manufacturers of wooden toy, who still maintain their existence as difficult. Within the activities such as toy design, repair and manufacturing workshops, the toy museum will be the center of interest. The toys and museums also mean introducing our culture to the whole world.

In our study, the importance of games, toys and toys museum on the education of children was revealed. The result of the study which is used the model of literature review, showed that it is a necessary the establishing healthy playgrounds and toy museums for increase quality and success in education.

Keywords: Preschool, Game, Toy, Toy Museum, Child Education.

\section{Oyun, Oyuncak ve Oyuncak Müzelerinin Çocuk Eğitiminde Aktif Olarak Kullanılması ve Başarıya Katkısı}

\section{Öz}

Oyun, oyuncak ve oyuncak müzeleri modern eğitiminin vazgeçilmez unsurlarıdır. Gelişmiş ülkelerde ve son dönemlerde bizim ülkemizde her türlü eğitimde oyun ve oyuncakların, oyuncak müzelerinin eğitim-öğretimde etkin şekilde kullanıldığını görmekteyiz. Hatta din ve ahlak öğretiminde oyun ve oyuncağın ciddi katkısının olduğu bilinmektedir. Uzmanlar oyunu şöyle tarif 
182 I M. ÖNDER / Oyun, Oyuncak ve Oyuncak Müzelerinin Çocuk Eğitiminde Aktif Olarak Kullanılması ve Başarıya Katkısı

etmektedirler: Belli bir amacı olan veya olmayan, kurallı veya kuralsız gerçekleştirilen, her durumda çocukların isteyerek ve hoşlanarak icra ettiği, bilişsel, fiziksel, duygusal, dilsel ve sosyal gelişimin temelini oluşturan gerçek hayatın bir parçası ve çocuk için en etkili öğrenme sürecidir. Dikkat edilirse bu tarifte çocuğun her türlü gelişimine katkıda bulunan ve isteyerek, severek gerçekleştirdiği bir eylemden bahsedilmektedir.

Oyuncak çocuğun hayatındaki en önemli arkadaşı, hatta sırdaşı durumundadır. Çocuklar oyun vasıtasıyla kendilerini denetlemeyi, kurallar koyarak bu kurallara uymayı öğrenirler. Onlar gerçek hayatta yapamadıkları hususları öncelikle öğrenmek ve daha sonra anlamak amacıyla oyun oynar ve oyun içerisinde çeşitli denemeler yaparlar. Bütün çocukların küçük yaşlardan itibaren hayallerinde bir oyun arkadaşları vardır. Onların bu arkadaşları genellikle bir veya birkaç oyuncaktır. Oyunlar ve oyuncaklar küçük çocuklar için sadece bir uğraş ve eğitsel faaliyet değildir. Aynı zamanda ruh sağlı̆̆ı gelişimlerine katkı yapan önemli bir etkinliktir. Oyun oynama ve oyuncakla oynama faaliyeti çocuklarda bulunması muhtemel rahatsızlıkların (otizm, öğrenme güçlüğü vb.) erken teşhis ve tedavisinde önemli bir imkân sunmaktadır. Güncelliğini koruyan ve çocuklarımızı zararlarından nasıl koruyacağımıza dair çareler aradığımız dijital bağımlılık konusunda oyun ve oyuncaklardan yararlanabiliriz.

Oyunlar ve oyuncakların farklı bilim dalları ile ilişkisinin yanında, kültür ile de sıkı bir ilişkisi vardır. Ülkemizde ve Dünyada artık önemli şehirler sadece kültürel ve tarihi mirasları, turizm hareketleri ile değil, çocuklara yönelik oyun ve oyuncak ağırlıklı eğitici mekânları ile rekabet etmektedirler. Oyun ve oyuncaklar ülkelerin eğitim sistemlerinin bir göstergesi, aynı zamanda tüm çocukların ortak dilidir. Oyun ve oyuncaklar bir ülkenin gelecek tasavvurunun kodlarını içinde barındıran çok önemli materyallerdir. Bugün dünyada farklı teknolojik alanlarda öne çıkmış ülkelerin bundan 50 veya 70 yıl öncesine bakarsak, işin temelinde çocuklar için üretilen ve kullanılan oyuncakların olduğunu görürüz. Japonya'nın o dönemde ürettiği oyuncaklar robot ve türevleridir. Bugün Japonya robot teknolojisinde rakipsiz demektir. Aynı dönemlerde $\mathrm{ABD}$ 'nin ürettiği oyuncaklar uzay araçları ve roket ağırlıklıdır. ABD bugün uzay teknolojisi konusunda ön sıralardadır. Çocuklar için üretilen oyuncaklar geleceğe dair yaratıcılığın bir göstergesidir. Bu nedenle önemle üzerinde durulması ve yetişkinlerin kafa yorması gereken bir alandır. 
Eğitimin en önemli amaçlarından birisi anlama, sorgulama, yenilikçi fikirler ve üretimle rekabet edebilme yeteneği kazanmış nesiller yetiştirmektir. Bu özellikleri kazandırmanın temel şartı çocuklarımızı oyun ve oyuncakla buluşturmaktır. Dünyada eğitim problemini çözmüş ülkeler, örgün eğitimi oyun, oyuncak ve oyuncak müzeleri ile entegre edebilmiş ülkelerdir. Günümüzde ilgi odağ1 olan tanınmış şehirler sadece tarihi ve turistik zenginlikleri olanlar değil; çocuklara yönelik altyapısı da zengin olan şehirlerdir.

Oyuncakların görselliğinden ziyade eğitici yönü ile öne çıtı̆̆ı ve toplandığ oyuncak müzeleri örgün eğitim kurumlarının tamamlayıcı unsuru durumundadır. Bu mekânlar çocuk eğitimine katkısının yanında, yerli oyuncak sanayiinin gelişmesine, kaybolmaya yüz tutmuş oyuncakların ve bunların etrafında gelişmiş milli kültürümüzün ortaya çıkarılmasına vesile olacaktır. Oyuncak müzeleri hala varlıklarını zor da olsa sürdüren geleneksel ahşap oyuncak üreticileri için teşvik unsuru olabilir. Müzelerin bünyesinde oyuncakların tasarım, tamiri ve imalat atölyeleri her kesim için ilgi odağı olacaktır. Oyuncaklar ve müzeler aynı zamanda kültürümüzü bütün dünyaya tanitmak demektir.

Alanyazın taraması modelini kullandığımız çalışmamızda; oyun, oyuncak ve oyuncak müzelerinin çocuk eğitimindeki önemi ortaya koyulmuştur. Çalışma sonucu, sağlıklı ve güvenli oyun mekânlarının oluşturulmasının ve oyuncak müzelerinin kurulmasının eğitimde kaliteyi arttıracağını ve yaratıcı çocukların yetişmesine imkân sağlayacağını göstermiştir.

Anahtar Kelimeler: Okul Öncesi, Oyun, Oyuncak, Oyuncak Müzesi, Çocuk Eğitimi.

\section{Giriş}

İnsanın doğuştan getirdiği yeteneklerin keşfedilmesi, bu yeteneklerin geliştirilmesi ve istendik yönde değiştirilmesi eğitimle mümkün olabilmektedir (Varış, 1988, 15). Bu faaliyetlerin gerçekleşmesi öncelikle eğitimciler, iyi hazırlanmış eğitim ortamları, uygun yöntemler ve bu süreçte kullanılacak materyallerle mümkündür. Oyun ve oyuncağın önemi burada ortaya çıkmaktadır. Oyunsuz ve oyuncaksız bir çocuk eğitimi mümkün değildir. Uzmanlar oyunu şöyle tarif etmektedirler: Belli bir amacı olan veya olmayan, kurallı veya kuralsız 
184 I M. ÖNDER / Oyun, Oyuncak ve Oyuncak Müzelerinin Çocuk Eğitiminde Aktif Olarak Kullanılması ve Başarıya Katkısı

gerçekleştirilen, her durumda çocukların isteyerek ve hoşlanarak icra ettiği, bilişsel, fiziksel, duygusal, dilsel ve sosyal gelişimin temelini oluşturan gerçek hayatın bir parçası ve çocuk için en etkili öğrenme sürecidir (Poyraz, 2017, 4). Oyun ve oyuncakların çocukların ahlak ve değer eğitiminde de önemli bir yeri vardır. Çocuklar oyun oynarken öncelikle kendi istek ve arzularını gerçekleştirirler. Başka çocukların etkisinde kalmadan oyun esnasinda edindikleri deneyim ve bilgi sayesinde kurallar ve değerler elde ederler. Otokontrol yeteneği kazanmış, sevgiyi ve sevmeyi, vicdani duyguları öğrenmiş olurlar (Balat, 2012, 39; Koglin - Petermann, 2013, 43; Sevinç, 2009, 18-19). Oyun imkânı bulan ve oyunla, oyuncakla yetişen çocukların bu imkânlardan mahrum olanlara göre daha uyumlu, daha sosyal, daha paylaşımcı ve daha yaratıcı oldukları gözlemlenmiştir (Akın, 2017, 84-85). Oyun oynamanın çocuklarda olumlu davranışların güçlenmesine, olumsuz davranışların da değiştirilebilmesine imkân sağladığı bilinmektedir (Yörükoğlu, 2008, 71).

Oyun ve oyuncağın farklı disiplinlerle sıkı bir ilişkisi vardır. Sosyoloji, dil, psikoloji, tarih, siyaset, coğrafya ve endüstri ile kısacası günlük yaşam ve toplum kültürü ile iç içedir (Onur, 2016, 17). Dünyanın farklı ülkelerinde ve bizde oyunlar, oyuncaklar ve oyuncak müzeleri incelendiğinde bu ilişkiyi görmek mümkündür. Eğitime engel olabilecek doğuştan ve sonradan oluşan rahatsızlıkların erken teşhisinde, çocuklara destek ve rehberlik hizmetlerinde oyun ve oyuncaklar çok ciddi katkılar sunabilmektedir (Bakırcıoğlu, 2013, 348; Çakar, 2017, 167 vd.; Poyraz 2017, 7). Oyunların ve oyuncakların tarihi seyri ve dünyada yaygınlaşmaları başta antropologlar olmak üzere birçok bilim insanı için kıymetli bilgiler içermektedir. Bazı oyunların bütün dünyada ve bizde aynı ismi taşıdığı (Kör Çebiş gibi) ve aynı biçimde oynandığı tespit edilmiştir (Poyraz, 2017, 9). Yaygınlaşmış oyunların içinde dil bilimciler için son derece önemli bilgiler gizlidir. Oyun esnasında çocuklarca söylenen türkü, şarkı, tekerleme, bilmece vb. sözlü unsurlar bölge ve toplum kültüründen izler taşırlar. (Şen, 2012, 405). Birleşmiş Milletler “Çocuk Haklarına Dair Sözleşme” yi 20 Kasım 1989 da kabul etmiştir. Sözleşmenin 31. maddesinin 1. fikrasında, "Taraf devletler çocuğun dinlenme, boş zamanını değerlendirme, oyun oynama ve yaşına uygun etkinliklerde bulunma; kültürel, sanatsal yaşama serbestçe katılma hakkını tanırlar" ifadeleri bulunmaktadır (Şen, 2012, 404; Doğru, 2017, 
3). Günümüz dünyasında Matematik ve Fen Bilgisi gibi sayısal ağırlıklı derslerin eğitiminde, hatta din ve ahlak eğitiminde oyunlardan, oyuncaklardan yararlanılarak derslerin çocuklara sevdirilmesi ve başarının arttırılması uygulamaları yapılmaktadır. Oyunla erken çocukluk eğitiminin buluşmasının temelinde, oyunun küçük çocuğun fiziksel, bilişsel, toplumsal ve duygusal gelişimine katkısına duyulan inanç yatmaktadır (Onur, 2016, 53).

Eğitimin en önemli amaçlarından birisi anlama, sorgulama, yenilikçi fikirler ve üretimle rekabet edebilme yeteneği kazanmış nesiller yetiştirmektir. Bu özellikleri kazandırmanın temel şartı çocuklarımızı oyun ve oyuncakla buluşturmaktır. Dünyada ilgi odağı olan Tokyo, Nürnberg, Paris, İstanbul, Milano gibi şehirler sahip oldukları tarihi ve kültürel zenginliklerini oyun, oyuncak ve oyuncak müzesi gibi her türlü eğitim alt yapısı ile geliştirmiş şehirlerdir. Dikkat çeken bu gibi şehirlerin düzenli oyun mekânları, oyuncak üretimi ve paylaşımı, oyuncak müzelerini bünyesinde barındırdığını görmekteyiz. Bütün dünyada çocuk eğitiminde önemli bir etkiye sahip Montessori Yöntemi'nde oyun ve oyuncaklar en önemli enstrümanlardır (Wilbrandt, 2009, 213 vd.) Çalışmamızda bu konular üzerinde durulmaya ve bu unsurların çocuk eğitimine katkısı incelenmeye çalışılmıştır.

\section{A- Oyun ve Eğitimdeki Önemi}

Oyunlar aslında hepimizin hayalleridir, hayaller ise yaşamımızdır. Her yaşta ve dönemde insanların oyuna ihtiyacı vardır. Oyunun kahramanı ise oynayan çocuk veya yetişkindir. Oyunun en önemli özelliği oynayanları eğitebilmesidir. Bu yüzden bütün eğitimciler oyunsuz bir çocukluğun mümkün olmadığını söylerler (Ögel, 2012, 4748). Tarihi süreçte Eğitim Bilimini Felsefe'den ayırarak ilk kez konu ile ilgili eserleri Türk-İslam bilginleri yazmışlardır. İbn-i Sina bu konuda önemli bir yere sahiptir. Eğitimin aşamalarından bahsederken (Piaget'den bin yıl önce) oyun oynamanın çocuk eğitimindeki büyük rolünü vurgulamıştır (Önder, 2014, 79). Piaget'in Bilişsel Gelişim Teorisi ya da "Genetik Epistemolojisi" (Miller, 2008, 54, 55) ne göre, çocukların düşünceleri doğuştan getirilen bilgiler etrafında şekillenmez. Onların dünya hakkındaki fikirleri genellikle kendiliğinden değil, zekâları vasıtası ile düzenlenmektedir. Yaş ilerledikçe ortaya çıkan 
186 | M. ÖNDER / Oyun, Oyuncak ve Oyuncak Müzelerinin Çocuk Eğitiminde Aktif Olarak Kullanılması ve Başarıya Katkısı

değişikliklerin bir düzene sahip olması, tecrübeler ve doğuştan gelen donanımlar arasındaki etkileşim, aslında düşüncelerimizin bizimle birlikte büyüdüğünü ve geliştiğini göstermektedir. Oyun ve oyuncak bilişsel gelişimi önemli ölçüde destekler (Senemoğlu, 2013, 35-40). Çocuklar için önemli olan onların oyunlar ve oyuncaklara yüklediği anlamlar ve işlevler, onlardan aldığı haz ve keyif ile onu kullanım biçimidir (Akın, 2015, 85; Aydın, 2011, 50).

Oyun oynama çocuklar için çok önemli bir "iş" tir. Yetişkinler için de durum aynıdır ama oyunun yetişkinlerde işlevleri değişiktir. Oyunun asıl görevi çocukların Dünya'ya sağlamaları gereken uyumu kolaylaştırmaktır. Çocuklar dünyanın ne olduğunu ve gerçekliğini oynadığı oyunla anlamaya çalışır. Arzu etmediği ve sevmediği durumlarla oyun oynayarak başa çıkmaya çalışır. Kullandığı dil ve kavramları geliştirmeyi oyun aracılığı ile sağlar. Toplum içindeki farklı rolleri oyun oynayarak denemeye çalışır. Gerçek hayatta her zaman hazır bulamayacağı uyarıcılara oyun vasıtasıyla ulaşabilir (Bacanlı, 2011, 113). Oyunları inceleyen Mildred Parten çocuk oyunlarını altı başlık altında toplar ve çocuk gelişimine yaptığı katkıları açıklar. Parten'in yaptığı altılı tasnif başlıkları şöyledir: Seyirci olma, Paralel etkinlik, Uğraşsız davranış, Yalnız Başına Oyun, Birlikte oyun ve İşbirliğine Yönelik Tamamlayıcı Oyun (Akt. Bacanl1, 2011, 114, 133). Bilişsel öğrenme kuramının fikir babası Piaget'de oyunları, geliştirdiği zihinsel öğrenme kuramına göre sinıflandırmıştır. O'na göre oyun, çocukların yaşadıkları deneyimleri anlamlandırma arzularının bir sonucudur ve bir uyum sürecidir (Erduran - Y1lmaz, 2016, 1-2; Şen, 2012, 408-409).

Oyunlarla ilgili diğer bir sinıflamada şöyledir: Harekete Dayalı oyun, Keşfe Yönelik oyun, Hayale Dayalı oyun, Duygu ve Kandırmaya Yönelik oyun ve Taklit oyunları (Heinelt, 2009, 77). Konu ile ilgili başka bir siniflamada ise Peter Smith oyunları, Sosyal Oyun, Lokomotor Oyun, Hayali Oyun, Nesnelerle Oyun olarak belirtir. Akgül ise Nesneleri Keşfedici Oyun, Manipülatif Oyun, Yaratıcı Oyun, Fantezi ve Dramatik Oyun, Fiziksel Lokomotor Oyun, Dil ya da Kelime oyunu şeklinde bir tasnif yapmaktadır (Akgül, 2016, 5). Bahsedilen oyunların tamaminda oyuncak temel objedir, çocukların en yakın arkadaşıdır, en önemli sırdaşıdır (Sezer, 2012, 239-240). Çocuğun zihinsel gelişiminde sosyokültürel yöne dikkat çeken Vygotsky, çocuğun oyun oynamasının 
sağladığı kazanımlardan bahseder. Ona göre çocuklar oyun vasıtası ile kendi kendini denetlemeyi, kurallar oluşturmayı ve bu kurallara uymayı öğrenirler. Gerçek hayatta yapmaları mümkün olmayan şeyleri denerler, anlamaya ve öğrenmeye çalışırlar (Şen, 2012, 408). Çocuklar oyun esnasında oynadikları oyuncak ve nesnelere bir anlam yüklerler. Kendileri için başlangıç safhasında hayali olan durumlar bir süre sonra bazı kuralları öğrenmesi, kendi gelişim alanının ilerisine geçmesi ve yakınsak gelişim alanını oluşturması sonucunu doğurur (Aydın, 2011, 53).

Çocuklar belli dönemlerde (bu dönemler genellikle 2-3 yaşları veya 9-10 yaşlarıdır) kendilerine hayali oyun arkadaşları edinirler. Sağlıklı bir gelişim sürecinde olması gereken bu durumda genellikle herhangi bir oyuncak çocuğun oyun arkadaşı ve sırdaşıdır (Önder, 2018, 147). Oyun ve oyuncak çocuklar için amaçsız bir uğraş değildir. Onların eğitimi ile birlikte ruh sağlı̆̆ gelişimine ciddi katkılar yapan, duyguları ve duygusal ilişkileri öğrenebilmelerine, bu tür ilişkileri arkadaşları ile başlatabilmesine ve geliştirebilmesine katkı sunan bir faaliyettir (Sezer, 2012, 240). Gray, oyunun çocukların ruh sağlığı üzerindeki olumlu etkilerini şöyle açıklamaktadır: Çocuklar oyunda içkin ilgi ve yetenekler geliştirir, karar verme, sorun çözme, özdenetim geliştirme ve kurallara uymayı öğrenirler. Duygularını düzenlemeyi, arkadaş edinmeyi, onlarla geçinmeyi öğrenirler. Oyunun varlığı çocukları mutlu eder, yokluğu ise mutsuz eder (Onur, 2016, 81). Montesssori oyuna farklı bir anlam yükler. Çocuğun asıl işi çalışmaktır. Çocuk doğası gereği hiç durmaz, her anının her dakikasının büyük önemi vardır. Hiç durmadan büyüdüğünden dolayı gelişimine katkı yapan ne varsa hepsine sarılır, uğraşır ve öğrenmeye devam eder. Bu yüzden oyun önemlidir ama asıl uğraşın yanında ikinci plandadır (Tepeli, 2014, 75). Alman Din Eğitimcisi Gottfried Heinelt, oyunun çocuğa günlük yaşamın vahametinden kurtulma ve yeni yaşam görevlerine hazırlanma imkânı tanıdığını söylemektedir (Heinelt, 2009, 78). John Dewey'e göre oyunun çocuklar için iki işlevi vardır: Oyun küçük çocuğun bilgiyi içselleştirmesini sağlar. Toplumu ve doğayı tanımak için özgür ve içsel olarak güdülenmiş bir etkinliktir (Onur, 2016, 52).

Oyun çocuklar ve yetişkinler için bir insanlık hakkıdır. Bedeni, ruhu ve zihni besleyerek sağlıklı olmayı sağlar. Çocukların uzmanlık 
188 I M. ÖNDER / Oyun, Oyuncak ve Oyuncak Müzelerinin Çocuk Eğitiminde Aktif Olarak Kullanılması ve Başarıya Katkısı

alanıdır, birbirleri ile ve çevre ile etkileşimini sağlar. Kendini keşfetme ve geliştirmesine katkı sağlar. Özgür bir ortam sağlayarak barış içinde yaşamayı, paylaşmayı öğretir. Yaşamı anlamlı, güvenli ve keyifli hale getirir. Yaratıcllık ve problem çözme için iyi bir fırsattır Özgüveni sağlar, kurallara uymayı öğretir. Sorumluluk duygusunu geliştirerek toplumsal rolleri benimsemeyi sağlar. (Güven, 2011, 73-74; Tuğrul, 2012, 182-183). Oyunla öğrenmede çocuklar tüm duyularını etkili şekilde kullanırlar ve bu durum öğrenmeyi kolaylaştırır. Bu açıdan diğer yöntemlere göre daha güçlü ve üstün bir yöntemdir diyebiliriz (Tuğrul, 2012, 183).

Adıgüzel, oyunla ilgili şu tespiti yapmaktadır:

“Oyun, yalnız bir eğlence aracı değildir. Oynayanın duygularının, çatışmalarının, eğilimlerinin, kendi istek ve çevre etkilerinin içine alındığı bir eylemdir. Sözgelimi çocuk kurduğu oyunda, amaçlarını, problemini, sevincini, öfkesini, sevgisini, nefretini çözmekte ve ifade etmektedir. Bu oyunlar aracılığıyla kendi gereksinimleri ile çevre şartları ve etkileri arasında denge kurmakta ve bir uyum oluşturmaktadır. Oyun duygusal bir ifade aracı olduğu gibi, çocuğun bir şeyler öğrenmesini ve yaratıclık yetilerinin gelişmesini de sağlar. Bu nedenle oyun öğrenmek için çok önemli araçtır" (Akt. Adıgüzel, 17.01.2020).

Oyun ve oyuncağın ve bunların gerçekleştirilebileceği uygun mekânların çocukların her türlü öğrenme kapasitesine katkıda bulunduğu, sosyal ve duygusal gelişimlerini güçlendirdiği, daha yaratıcı, daha özgüvenli, daha az sindirilmiş ve daha dikkatli olmalarının yolunu açtığı yapılan araştırmalarla kanıtlanmıştır (Sahlberg, 2018, 42). Aslında oyun ve oyuncak çocuğa okulu, dersi ve öğretmeni sevdirmekte, seven öğrenci ise daha kolay öğrenmekte ve başarılı olmaktadır.

\section{B- Oyun, Oyuncak ve Din Eğitimi}

Oyun ve oyuncağın farklı disiplinlerle sıkı bir ilişkisi bulunmaktadır. Diğer bir ifade ile oyun ve oyuncak kültürün bir yansımasıdır (Onur, 2016, 17). Bu ilişki din ve inanç boyutunu da içermektedir. Çocukların çevrelerini anlamaları ve anlamlandırmaları oyun oynama ve taklit etme gibi duygusal ve zihinsel süreçlerle mümkündür. Dini duygu da bunlara paralel olarak gelişmektedir (Oruç, 2014, 155). Dolayısı ile bu duygunun sağlıklı bilgi ve iyi bir rehberlikle yönlendirilmesi gerekir. Özellikle soyut dini kavramlarla karşılaşan 
çocuklara anlayabileceği basit bir dil ile ve hikâye-masal tekniğinden faydalanarak açıklamalar yapılabilir. Oyun bunun için iyi bir imkân sağlar. İlk çocukluk döneminde çocuğa verilecek oyuncaklar arasında dini yaşantıyı da temsil edebilecek, hatırlatacak uyarıcılar bulunmalıdır. İbadethanelerin resimleri veya maketleri, dini ritüellerde kullanilan eşyalar gibi. Böylece çocuk dini eşyanın farkına varabilecek, bunlar hakkında soru sorabilecektir. Namaz ibadeti, ramazandaki iftar sofraları, kandil gecelerindeki özel yaşantılar çocuklar için önemlidir (Selçuk, 1991, 51). Bilgin oyunun çocuk eğitimindeki öneminden bahsederken; çocuklar oyunu oyun olsun diye oynamazlar, ilk iki yılda amaçsız gibi görünen hareketler giderek bir amaca yönelir. Çocuklar oyun ile hem beden hem de ruh sağlığı kazanırlar ifadesini kullanmaktadır (Bilgin, 1987, 147). Çocuğun herhangi bir davranışı taklit veya özdeşim yolu ile öğrenmesi söz konusudur. Eğer taklit edilmesi gereken davranış çocuğun sevdiği birisi tarafından sergileniyorsa etkili olma şansı daha yüksektir. Oyunu ve oyuncağı seven çocuklar, bunları kendisine veren ve birlikte oynayan yetişkinleri de sevecektir. İçinde bulunduğu yaş gurubu özelliklerine uygun ahlaki-dini öğüt ve davranışlar çocuk üzerinde etkili olabilecektir.

Oyun oynama çocukların her türlü ahlaki ve dini değerleri öğrenmesi için fırsat sağlar. Paylaşma, kurallara uyma, yardımlaşma, iyi ve güzel olanı tercih etme, teşekkür etme, tertipli ve düzenli olma, temizlik, dürüstlük, adab-1 muaşeret kuralları vb. davranışları içselleştirmede oyunlardan büyük ölçüde yararlanılabilir. İslam dininde çocuk ve oyun söz konusu olduğunda hiçbir kısıtlamadan bahsetmek mümkün değildir (Bilgin, 1987, 146-149). Ortaçağda ilk defa din eğitiminin önemine dikkat çeken J. A. Comenius şöyle demektedir:

\footnotetext{
“Bir boya ile ilk defa boyanmış bir yün, boyanın rengini öyle sağlam bir şekilde alır ve emer ki onu başka bir renge boyamak kolay olmaz. Yaş bir ağaç kolayca bükülür ve çember yapılabilir. Fakat kuruduktan sonra onu eski haline getirmek isterseniz kırılır. Tıpkı bunun gibi ilk izlenimler insan ruhunda öyle sağlam, kuvvetli ve derin izler meydana getirir ki, onları beyinden söküp çıkarmak adeta olanaksızlaşır" (Comenius, 1964, 49).
}

Alman Din Eğitimcisi Günter Stachel, çocuklarla birlikte oyun oynamanın önemli bir din eğitimi imkânı sunduğunu, sevgi, dostluk ve benliğin gelişmesini sağladığını, kararlılık, centilmenlik kazandırdığını 
190 I M. ÖNDER / Oyun, Oyuncak ve Oyuncak Müzelerinin Çocuk Eğitiminde Aktif Olarak Kullanılması ve Başarıya Katkısı

söyler (Stachel, 2009, 40). Montessori'nin kurduğu Casa dei Bambini (Çocuklar Evi) isimli okulda, her faaliyetin dini bir yönü bulunmaktadır. $\mathrm{Bu}$ faaliyetlerin amacı hayat için, barış için, karakter ve ruhsal eğitim olarak belirlenmiştir. Din eğitimi vermek için belli bir yaşı beklemek gereksizdir. Bütün çocukların içinde "mihenk taşı" denilen bir ölçüt vardır. Çocuklar diş dünyadaki algı ve izlenimlerini bu mihenk taşına vururlar. Erken dönemdeki din eğitiminin etkisi ömür boyu devam eder. Rousseau ve takipçilerinin, belli yaşa gelinceye kadar din eğitimine gerek görmemeleri herhangi bir deneye ve kanita dayanmayan pedagojik yöntemlerdir (Göçeri, 2019, 188-190).

Oyun ve oyuncağın sevgi ile yakından ilişkisi vardır. Çocuk eğitiminin temeli ise sevgiye dayanmaktadır. Çocuk oyun ve oyuncakla oynama esnasında hem sevgiyi tadar, hem de başkalarını sevmeyi öğrenir. Oyun çocuğun gelişmesi ve kişilik kazanması için sevgiden sonra gelen en önemli ruhsal besindir (Poyraz, 2017, 4). Sevgi başka birçok duygunun gelişmesine hem kaynaklık eder hem de gelişmesine katkıda bulunur (Oruç, 2014, 150). Yörükoğlu çocuğun ruh sağlığının sevilmek ve oynamakla daha olumlu olacağını belirtir (Yörükoğlu, 1988, 47). Tolstoy sevginin gücünü şöyle açıklar: "Anladım ki insanın kalbine sevgi hükmeder ve bu sevgi insanı Allah'ın varlığına götürür" (Tolstoy, 2011, 48-49).

Özellikle arkadaşlarla birlikte oynanan oyunların ahlaki kuralların öğrenilmesinde ve benimsenmesinde etkili olduğu bilinmektedir. Grupla oynanan oyunlar çocuklar için üç önemli katkı sağlar. Birincisi, çocuklar oyunlar aracilığı ile zihinsel ve ahlaki bağımsızlık kazanmaya başlarlar. İyi ve kötü ayrımını kendi kendilerine yapmaya başlarlar. İkincisi, benmerkezci düşünmeden uzaklaşarak diğerlerinin bakış açısı ile olaylara bakmaya bakarlar, empati kurabilirler. Son olarak, sorular ve problemler oluşturmada özgüven kazanarak bunlara çözümler üretebilecek araçları bulma yeteneği kazanırlar (Köylü - Oruç, 2017, 36). Eğitimcilerin hemen tamamı okul öncesi dönemin dini ve ahlaki açıdan da kritik bir dönem olduğu, çocukların bu alandaki ihtiyaçlarının sağlıklı olarak tatmin edilmesi gerektiği görüşündedirler. 


\section{C- Oyuncağın Tarihi Serüveni}

Tarihi süreçte ilk oyuncakların Mısırlılara ait olduğu bilinmektedir. O dönem çocuklarının M.Ö. 5. yüzyılda tahtadan yapılmış atlarla ve M.Ö. 2. yüzyılda topaçlarla oynadıklarını arkeolojik buluntular ortaya koymuştur. Eski çağlardan günümüze kadar gelen birçok nesnenin dini objeler mi yoksa oyuncak mi olduğu konusu hala tartışılmaktadır Kesin olan şudur ki, çocukların o dönemde de gelecekteki rollerine, yani hayata hazırlanmaları için oyuncaklar daima önemini korumuştur. A. Burton, oyuncakların en büyük cazibesi bize dünyayı minyatür halinde göstermeleridir ifadesini kullanır (Onur, 2010, 21)

Oyuncak tarihçisi Fredlund'a göre, dünyanın ilk ve en eski oyuncağının top olması kuvvetle muhtemeldir (Özgül - Kanak, 2019, 68). Kardan veya çamurdan yapılan toplar eski dönemlerde yetişkinlerin ve çocukların eğlenmesi için kullanılan önemli bir nesne olagelmiştir. İskoçya'da bulunan ve 4000 yildan daha eski dönemlere tarihlenen taştan yapılmış toplar oyuncak tarihi için önemli belgelerdir. Bunun yanında farklı materyallerden yapılmış bebekler, bilyeler, topaç ve tahta atlar, çıngıraklar, çemberler ve oyuncak askerler tespit edilen en eski oyuncaklardır (Onur, 2016, 63).

Türk tarihinde ve kültüründe oyun ve oyuncağın önemli bir yeri vardır. İlk Türklerden günümüze kadar bu önem hiç azalmamıştır. Evliya Çelebi Seyahatname adlı eserinde İstanbul esnaflarından bahsederken Eyüp semtinde 100 kadar oyuncakçı dükkânı ve bu işle meşgul olan 105 kadar esnaftan bahseder. Çocukların sünnet törenlerinde mutlaka Eyüp Sultan'a ziyarete götürüldügünü ve bu ziyaret esnasında oyuncaklar alındığını biliyoruz. Eyüp semtinde ilk oyuncağın 18. yüzyılda Dökmeci Hasan Ağa tarafından yapıldığı, Gümüşsuyu'ndan Darbukacı Halil Efendi ile Küçük İsmail Efendi'nin de oyuncak atölyeleri olduğu kayıtlıdır (Poyraz, 2017, 25).

Oyuncakların seri olarak üretimine ise 18. yüzyılda başlandığ1 görülmektedir. Öncelikle tahta oyuncakların, sonra sırasıyla kâğıttan, tenekeden üretilmiş oyuncakların, daha sonra kurmalı, buharlı ve elektrikli, pilli oyuncakların üretildiğini görüyoruz. Tanınmış oyuncak fabrikaları ise 1800'lü yılların sonunda seri oyuncak üretimine başlamışlardır. Oyuncak ve oyuncak üretimi söz konusu olduğunda 
192 | M. ÖNDER / Oyun, Oyuncak ve Oyuncak Müzelerinin Çocuk Eğitiminde Aktif Olarak Kullanılması ve Başarıya Katkısı

akla ilk gelen ülke Almanya'dır. Oyuncağı düzenli bir sanayi ürünü haline getiren ilk ülke Almanya'dır. Özellikle Nürnberg bölgesi bu konuda merkez durumundadır. Endüstri devriminin etkisiyle söz konusu dönemde önce teneke oyuncaklar üretilmiş ve yaygınlaşmıştır. Başta araba, uçak ve gemi oyuncakları teneke oyuncaklar içerisinde en fazla ilgiyi görmüşlerdir (Onur, 2016, 66-67).

İkinci Dünya Savaşı devam ederken ekonomik sıkıntılar nedeniyle pek çok sektör ve mamulde görüldüğü gibi oyuncak sektörü ve imalatında da sıkıntılar yaşanmıştır. Çoğu oyuncak atölyeleri ve fabrikalarının savaş dönemlerinde silah üretimi yapan tesislere dönüştürülmesi son derece üzücüdür. Bu durum savaş yıllarında evlerde yapılan basit oyuncaklarda bir artışın ortaya çıkmasına yol açmıştır. 20. yüzyılın ikinci yarısından itibaren öncelikle çocukların güvenliği ve daha ucuza mal olmasından dolayı plastik oyuncakların ağırlık kazanması söz konusudur. Bu dönemin hemen akabinde modern teknolojinin de devreye girmesiyle Japonya oyuncak sanayiinde zirveye oturmuştur. 20. yüzyılın sonlarına doğru Japonya oyuncak pazarındaki hâkimiyetini Çin, Hong Kong, Malezya, Taiwan, Singapur, Malezya gibi Uzakdoğu ülkeleri ile paylaşmak zorunda kalmıştır. Günümüzde piyasaya sunulan oyuncakların büyük çoğunluğu Çin yapımıdır ve sağlıklı, güvenli olup olmadıkları eğitimciler ve uzmanlarca tartışılmaktadır. Ülkemizin 2018 yılı itibarıyla yurtdışından oyuncak ithali için yıllık 2 milyar dolara yakın bir para harcadığını dikkate alırsak, yerli ve milli oyuncak üretiminin ne kadar önemli olduğu ortaya çıkmaktadır. Dijital oyunlar iyi bir altyapı ile ve eğitici yönü ön plana çıkarılarak hazırlandığında çocukların akademik ve sosyal başarılarına katkı yapabilmektedir. Aynı zamanda yerli ve yabancı kullanıcılara kendi kültürümüz ve değerlerimiz konusunda farkındalık oluşturabilmektedir. TÜiK verilerine göre ülkemizin dijital oyun sektöründe 1 Milyar dolar civarında ihracatının olması önemli bir gelişmedir (aa.com.tr, 14.12.2019).

Oyuncaklar sadece çocuklara yönelik basit nesneler değildir. Yetişkinler tarafından tasarlanan ve üretilen oyuncaklar toplumların ve ülkelerin gelecek tasavvurlarını, zihinsel kodlarını içinde barındırırlar ve çocuklara motivasyon sağlarlar. Bunun basit bir örneğini Almanya'da Hitler döneminde görmek mümkündür. Hitler ikinci dünya savaşından 
önceki yıllarda "düşünceler çocuklarla büyür" anlayışı ile 1933 yılında "Alman Askerleri Oyuncak Seti" ni ürettirerek ailelere dağıtmıştı. Sonradan Barbie bebeklerini üreten fabrikaya dönüşen tesiste üretilip dağıtılan bu asker seti oyuncağı ile İkinci Dünya Savaşından yıllar önce Alman halk1 üzerinde ciddi bir alg1 ve motivasyon oluşturulmuştur. Uzmanlar savaşın bu algı ve motivasyonla kazanıldığını ileri sürmektedirler (Akın, 2016, 7). Dünyada ve ülkemizde mevcut oyuncak müzelerinde çok farklı oyuncaklar sergilenmektedir. Sergilenen bu oyuncaklara göz attığımızda çok önemli bir ayrıntı dikkatimizi çekmektedir: Günümüzden 50-60 yıl önce Japonya'da üretilen çocuk oyuncaklarının ana teması, cinsi robot ve türevleri ağırlıklıdır. Bugün Japonya'nın söz konusu alanda rakipsiz olduğunu biliyoruz. Aynı şekilde o dönemlerde ABD'de üretilen oyuncaklar ise daha ziyade uzay ve uzay araçları yoğunlukludur. ABD uzay ve uzay teknolojisinde dünyada en ileri seviyededir. Bu başarıların temelinde onlarca yıl öncesindeki çocuk oyuncakları yatmaktadır. Çocukluğumuzu hatırlayalım, o yıllarda çok sevdiğimiz oyuncaklardan birisi kâğıt veya plastikten yapılmış fırıldak adı verilen küçük rüzgârgülleri idi. Günümüzde dünyada ve bizim ülkemizin her yerinde çevre dostu (RES) Rüzgâr Enerji Santralleri olarak dönmeye devam ediyorlar. Bütün çocukların ilgi duyduğu ve bir dönem çok yaygın olarak oyuncak sektörüne giren robot oyuncaklar, başta sanayi üretimi olmak üzere artık günlük yaşamın her alanında yoğun olarak kullanılmaktadır. Şekil değiştiren ve dijital ağırlıklı özellikleri olan oyuncak arabalar dünyanın her yerinde kullanıma girmeye başladılar. Kâğıttan yaptığımız ve bir iple bağlayarak uçurduğumuz basit uçurtmalar hemen her alanda yoğun olarak kullanılan Drone'ların ilk prototipi değil midir? Bütün bunlardan şöyle bir sonuç çıartmak mümkündür: Bugünün oyuncakları yarının teknolojisinin ipuçlarını ve zihinsel kodlarını içinde taşımaktadır. Bu yüzden oyuncak tasarlamak, üretmek, kullanmak ciddi bir iştir. Ülkenin eğitim seviyesinin de göstergesi anlamına gelmektedir (Önder, 2018, 147-148).

Günümüzde elektronik ya da akıllı oyuncakların istilasından bahsedebiliriz. Oyuncağın en iyisi, oynayan çocuklara bilişsel, duyuşsal katkı yapan, araştırma, deneme, keşfetme, yaratıcı olma imkânı veren oyuncaktır. Hâlbuki söz konusu oyuncaklar önceden programlanmış ve çocuğa yapabilecek fazla bir şey bırakmamaktadır. Bu durumda mevcut 
194 | M. ÖNDER / Oyun, Oyuncak ve Oyuncak Müzelerinin Çocuk Eğitiminde Aktif Olarak Kullanılması ve Başarıya Katkısı

elektronik oyuncaklar gerçekte "akıllı" midır diye sormamız gerekiyor (Erduran - Yılmaz, 2016, 5). Elektronik oyuncakların başka sıkıntıları da vardır. Öncelikle çocuklarımızı dış dünyadan tamamen koparmakta, evlere hapsetmektedir. Bütün çocukların ulaşamayacağı kadar pahalı olmaları da ayrı bir problemdir. İç mekânlara kapanarak zaman geçiren çocukların ise doğayla, çevresi ve arkadaşları ile bağının azaldığı, sonuçta olumsuz davranışların gelişmesine neden olduğu görülmektedir (Onur, 2016, 83). Akıllı ya da elektronik oyun ve oyuncakların çocukları asosyal yaptığı, beslenmeye bağlı problemleri ortaya çıkardığı, dil gelişimini engellediği, aile içi iletişimi zedelediği bilinmektedir. En önemlisi de dijital bağımlılık gibi bütün toplumu saran ve neredeyse bir hastalık halini alan alışkanlığı daha da yaygınlaştırmadaki katkısıdır. Kendimizin tasarlayacağı, üreteceği oyuncaklar bu sıkıntıları gidermede önemli rol oynayacak, ithal oyuncak ve onların lanse ettiği yabancı kültür dayatmasına karşı bir duruş olacaktır (Bee - Boyd, 2009, 782-783; Dilci, 2016, 42; Göka, 2017, 119-133).

Oyuncak kavramı ilk bakışta sadece küçük çocukları ilgilendirir gibi gözükse de, aslında yetişkinleri de yakından ilgilendirir. Çünkü bugünün çocukları geleceğin büyükleri olacaklar ve onlar da kendi çocukları için oyuncaklar tasarlayıp, üretecekler, eğitimde kullanacaklardır. Diğer bir ifade ile oyun, oyuncak ve bunların bilinçli olarak kullanılması eğitime, geleceğe yapılacak en önemli yatırımlardan birisidir. İsveç'te 1873 yılında kurulan Kuzey Halkları Müzesi yetkilileri, "Oyuncaklar çocukları eğlendirmek için çoğunlukla yetişkinler tarafından yapılır. Genellikle yapıldıkları dönemin yaşamını anlatırlar" ifadesini kullanmaktadır (Onur, 2010, 23).

Eğitimci Günter Stachel, çocuklarla beraber oyun oynamanın çok önemli kazanımlar sağladığını, oyun oynamanın tamamen teknoloji hakimiyetinde olan günümüz dünyasının karmaşa ve çeldiricilerinden çocukları koruyacağını ve kendi dünyalarını kurmalarına imkân sağladığını belirtir (Stachel, 2009, 40, 41). Aslında oyunu, oyuncağ1 ve bunların eğitsel gücünü göz ardı etmek, çocuklara yapılacak en büyük haksızlıktır (Akın, 2017, 85). Yörükoğlu'nun sözleri bu konunun önemini ortaya koyuyor: Oyun çocukların yaratıcılığına fırsat sağlayan bir ortamdır. Onlar kendi sınırlı dünyalarını oyunlar vasıtasıyla aşarak 
genişletir. Oyun oynayan bir çocuk kendi hayal dünyasını kurarak içinde dolaşır. Ancak işlediği ve canlandırdığı konular gerçek hayatla bağlantılıdır Gerçek hayatta görüp algıladıkları hususları oyunlarının içine aktarırlar, kendilerine has bir yorum gücü ile birleştirip bütünlerler. Oyun esnasında çocuklar yetişkinler kadar güçlü ve beceriklidir. Üzerine bindiği aslında bir sopa veya dal parçası değil, yeri geldiğinde her engeli aşan güçlü bir attır. Oyuncak uçağı kendisini dünyanın her yerine götürebilen gerçek bir uçak gibidir Elindeki. Plastik veya metal oyuncak tabancası ile herkesten güçlü olduğunu düşünür." (Yörükoğlu, 2008, 69). Eğitimcilerin çoğuna göre çocuklar işlem öncesi dönemde etraflarındaki cansız nesneleri de canlı telakki ederler. Oyuncaklar bu nesnelerin başında gelmektedir (Bacanl1, 2011, 93).

Oyuncakların görselliğinden ziyade eğitici yönü ile öne çıktığı ve toplandığı oyuncak müzeleri örgün eğitim kurumlarının tamamlayıcı unsuru durumundadır. Bu mekânlar çocuk eğitimine katkısının yanında, yerli oyuncak sanayiinin gelişmesine, kaybolmaya yüz tutmuş oyuncakların ve bunların etrafında gelişmiş milli kültürümüzün ortaya çıkarılmasına vesile olacaktır. Oyuncak müzeleri hala varlıklarını zor da olsa sürdüren geleneksel ahşap oyuncak üreticileri için teşvik unsuru olabilir. Müzelerin bünyesinde oyuncakların tasarım, tamiri ve imalat atölyeleri her kesim için ilgi odağı olacaktır. Oyuncaklar ve müzeler aynı zamanda kültürümüzü bütün dünyaya tanıtmak demektir.

Oyuncaklar ve bir araya toplandıkları oyuncak müzeleri düşlerimizin ve hayallerimizin tarihini içerir. İnsanlar yaş farkı olmaksızın önce hayal eder sonra gerçekleştirirler. Aslında her şeyimiz hayallerle başlar (Akın, 2016, 85). Ülkemizde oyuncak müzeleri Sunay Akın rehberliğinde başta İstanbul olmak üzere, Ankara, İzmir, Antalya ve Gaziantep gibi şehirlerde kurulmuşlardır. Çocukların yoğun ilgisini çeken ve örgün eğitim kurumlarının tamamlayıcısı konumundaki bu müzelerin her ilimizde kurulması gereklidir. Ülkemizde ilk oyuncak müzesi 1990 yılında Ankara Üniversitesi Eğitim Bilimleri Fakültesi bünyesinde kurulmuştur. Müzenin amacl; “Türkiye'de yaşanan hızlı değişim ve gelişim sürecinde kaybolmaya yüz tutmuş oyuncakları toplayarak, koruma altına alarak, yeni yetişen nesillere aktarmak ve tanitmak" olarak açıklanmaktadır (Karadeniz - Artar, 2017, 479). Müzede oyuncaklar bir tasnife tabi tutularak; geleneksel olanlar, 
196 | M. ÖNDER / Oyun, Oyuncak ve Oyuncak Müzelerinin Çocuk Eğitiminde Aktif Olarak Kullanılması ve Başarıya Katkısı

fabrikasyon olanlar, yabanci olanlar, antik olanlar ve yeni olan oyuncaklar şeklinde sergilenmektedir. Oyuncak müzeleri bilim insanları tarafından, çocuk kültürünün araştırılmasına hizmet eden bilimsel bir kuruluşlar olarak kabul edilmektedir (Onur, 2010, 24). Londra'da bulunan Bethnal Green Çocuk Müzesi üç bölümden oluşur. Bu bölümlerden birisi de "Çocukluğun Toplumsal Tarihi" adını taşımaktadır. Müze yetkilileri bu bölümün amacını "Tarih yakın zamana kadar büyük adamların ve savaşların tarihi olarak kalmış, ailenin ve çocukluğun tarihi uzun zaman göz ardı edilmiştir. Müzenin amacı çocukluğun tarihini çocuklar tarafından yapılmış şeyler aracılığı ile araştırmak ve saptamaktır" şeklinde ifade etmektedir (Onur, 2010, 23). Dünyada başta İngiltere ve Almanya olmak üzere, ABD, Fransa, İtalya, Japonya ve Rusya'da bulunan oyuncak müzeleri çok eski ve köklü bir geçmişe sahiptir. Buralarda sergilenen oyuncaklar teknolojinin gelişmesine paralel olarak değişiklik göstermektedir. İlk dönemlere ait olanlar topraktan yapılmıştır. Daha sonra tahta oyuncaklar, teneke oyuncaklar ve elektronik oyuncaklar formuna dönüşmüştür.

Eğitimcilerimizden biri olan Satı Bey, dönemin Maarif Nazırı Emrullah Efendi'ye sunduğu bir layihada (1909) okul müzelerini ve bu müzelerin önemini dile getirmiştir. Okul Müzeleri ile ilgili görüşlerini şöyle belirtmektedir:

“Bu müzeleri gezen erbab-1 merak ve ihtisas masrafsızca, kolaylıkla tetkikat icrasına muvaffak olur. Muallimler ve talebeler bütün dersleri suhuletle (kolaylık), ve vuzuh (açıklık) ile tefhim (anlama) ve telkine medar (sebep) olacak vesaiti bulurlar. Müzeler mekteplerin vezaif-i talimiyesini (öğretim görevi) fevkalade teshil eder (kolaylaştırır). Müzeleri ziyaret etmiş olan bir çocuk için dersler büsbütün meçhul ve yeni değildir" (Mustafa Satı, 1326, 33).

Ülkemizde nüfusun yoğun olduğu yerleşim merkezlerinde okullaşma oranında belli bir mesafe kaydedilmesine rağmen, örgün eğitimin tamamlayıcı unsuru olan oyuncak müzesi, park, sanat, spor ve etkinlik merkezi sayıları yetersizdir. Bu tür mekanların akademik başarıyı ve kalıcı öğrenmeyi desteklediği görülmektedir. Başta üniversitelerimiz olmak üzere, konuyla ilgili tüm kurum ve kuruluşların koordineli bir çalışma ile bu problemi çözmeleri mümkündür. Çoğu üniversitemizde Eğitim Fakültesi ve bu fakültelerde okul öncesi eğitimi (temel eğitim) bölümü bulunmaktadır. Bu bölümde yoğun olarak, diğer 
bölümlerde de program içinde materyal tasarımı, yaratıcılık ve okullarda uygulama dersleri bulunmaktadır. Söz konusu dersler önemli ölçüde oyun, oyuncak ve bunların eğitimde kullanılması ile ilgilidir. Son dönemlerde yaygınlaşan "Montessori Sinıfları"nda oyuncak, oyuncakların tasarımı ve üretimi, en verimli şekilde sınıflarda kullanılması ana temadır. Bu nedenle bütün şehirlerde oyun, oyuncak ve oyuncak müzelerinin öğrencilerin kullanımına sunulması gerekmektedir. Eğitim problemini çözmüş ülkelerin bizden en önemli farkı, öğrencilerinin bu tür mekânlara kolayca ulaşabilmesi ve ilgi duyduğu alanla ilgili etkinlikler yapabilmesidir.

Ülkemizde konu ile ilgili bazı örnek etkinliklere rastlamak mümkündür. Muğla - Yerkesik'te her yıl gerçekleştirilen “Otantik Oyun ve Oyuncak Şenliği" buna örnektir. Şenliğin amacl, kaybolmaya yüz tutmuş eski çocuk oyunlarının günümüzde yeniden canlandırılması olarak belirtilmektedir. Başta üniversite olmak üzere, ilgili tüm kurumların ortaklaşa gerçekleştirdiği etkinlik, sadece oyun temelli olmayıp, aynı zamanda el yapımı oyuncakların üretimi, bunların sergilenmesi ve kullanılmasını da içermektedir. Etkinliğin başta turizm olmak üzere, öğrencilerin sosyalleşmesine, paylaşmasına büyük katk1 sağladığı, yaygın elektronik oyun ve oyuncak dayatmasına karşı çıkarak, yaratıcı, üretici ve kişilik kazanmış bireylerin yetişmesine imkan oluşturduğu düşünülmüştür. Şenlik boyunca eski Türk çocuk oyunları (ip atlama, bilye, çelik çomak, seksek, çember çevirme, dokuztaş, dama gibi) icra edilmektedir (Milliyet, 28 Mayıs 2015). İzmir'de her yıl Mart ayının ilk yarısında yapılan Kukla Şenlikleri ulusal ve uluslararası düzeyde ciddi ilgi görmektedir. İstanbul'da Türkiye'nin ilk oyuncak müzesi olan ve Sunay AKIN tarafından kurulan Müzede de sadece oyuncaklar görsel olarak kullanılmamakta, her hafta farklı temalarla çocukların bizzat katıldığı etkinlikler gerçekleştirilmektedir (KaradenizArtar, 2017, 483-484).

Yakın zamanda Millî Eğitim Bakanlığı ile Kültür ve Turizm Bakanlığı arasında imzalanan bir protokole göre; öğrenciler tarih, coğrafya, geometri, matematik gibi dersleri müzelerde ve tarihi eserlerde yapabileceklerdir. Böyle bir uygulama hem dersi öğrencilere sevdirecek hem de öğrenmeyi kalıcı hale getirecektir. Onur'a göre bütün müzelerde olduğu gibi oyuncak müzelerinin de koruma, araştırma ve 
198 I M. ÖNDER / Oyun, Oyuncak ve Oyuncak Müzelerinin Çocuk Eğitiminde Aktif Olarak Kullanılması ve Başarıya Katkısı

eğitim işlevi vardır. Bu işlevler iç içedir ve birbirlerini beslerler (Onur, 2010, 21). Örgün eğitimin oyun, oyuncak ve oyuncak müzeleri ile desteklenmesi çocuklar için yaşam zenginliği anlamına gelmektedir. Yaşam zenginliği ise çocukların çevreye uyumunu ve öğrenmelerini kolaylaştırır. Aşık, Seksek, Topaç, Kuş, Cüz, Karagöz ve Hacivat gibi geleneksel oyunlar (Yeşil, 2018, 36-48) bu amaçla kullanılabilir. Her bölgenin geçmişte kullanılan oyuncakları derlenerek sergilenebilir ve çocukların yeni tasarımlar yapması teşvik edilebilir.

Sosyal, sanatsal etkinlik alanları ve oyuncak müzeleri okullarda verilen eğitim kadar çocuk gelişiminde pay sahibidir. Bizde ve gelişmiş ülkelerdeki örnekler ve uygulamalar bu görüşü doğrular niteliktedir. (Karadeniz - Artar, 2017, 479). Barselona, Kopenhag, Antalya, Vancouver, Helsinki gibi şehirlerin "Çocuk Dostu Kentler" olması boşuna değildir. Buralarda çocuklar için mükemmel tasarlanmış, her türlü aktivitenin yapılabileceği özel alanlar ve mekânlar ayrılmıştır. Tarihi doku, müzeler, eğlence merkezleri, sergiler, bilimsel deneylerin yapıldığı mekânlar, yiyecekler ve üretim aşamaları, spor tesisleri ve futbol müzesi ile Barcelona çok güzel bir örnektir (Özçapkın, 2019, 117128). Kopenhag'da çocuklara yönelik merkezde bulunan "Duyular Tüneli" öğrenmeye gerçekten çok kalıcı ve büyük bir katkı yapmaktadır. Antalya'daki Dinopark, denizaltı akvaryumu ve kumsallarda özgürce oynamak çocuklar için eşsiz ve kalıcı deneyimler sunmaktadır. Vancouver'da balinalara eşlik eden dalgıçlar, uzay ve keşif meraklısı çocuklara hitap eden Planetaryum, Helsinki'deki zengin parklar ve bisikletle gezinti yapma imkânı çocuklar için vazgeçilmez mekânlar olarak ilgi odağı olmayı sürdürmektedir (Özçapkın, 2019, 120-127). Amerikan Pediatri Akademisi tarafından 2013 yılında yayınlanan raporda "Bilişsel işleme becerisi ve akademik performans, yoğun sınıf içi faaliyetler esnasında düzenli aralıklarla mola verilmesine bağlıdır. Bu hem ergenler, hem de küçük çocuklar için geçerlidir. Molaların etkili olabilmesi için öğrencinin zihnen gevşemesine imkân tanıyacak sıklıkta ve uzunlukta olmalarına dikkat edilmelidir" (Sahlberg, 2018, 46) ifadeleri kullanılmaktadır. Bu tespitler, çocuklara örgün eğitim imkânı kadar, oyun ve oyuncakla vakit geçirebilme imkânının da sunulması gerektiğini belirtmektedir. 
Eğitimde örnek ülkeler olarak kabul edilen Danimarka ve Finlandiya'da bilişsel dikkati ve derinlemesine düşünmeyi gerektiren derslerin öncesinde veya sonrasında çocukların temiz havada ve rahat bir ortamda koşup, oynamalarının öğrenme kapasitesini arttırdığ görülmüştür. Bir öğretmen konuyu destekler mahiyette: "Sadece anlatılan derse daha iyi odaklanmakla kalmıyorlar, ayrıca tartışma, sosyalleşme, takım oluşturma ve arkadaşlık kurma konusunda da daha başarılı oluyorlar" (Akt. Sahlberg, 2018, 48) ifadelerini kullanmıştır. Bu ülkelerde "kişiselleştirilmiş öğrenme" temel ilkedir. Müfredat programı çocuklarla birlikte planlanır, ev ödevi azdır, eğitimde oyunun rolünün ve değerinin kanıtı her yerde görülür (Onur, 2016, 75). Ülkemizde 2019 yılı Mart ayının sonlarında Milli Eğitim Bakanı tarafından açılanan ve pilot bölge olarak seçilen Antalya' da uygulanacağı belirtilen $40 \mathrm{dk}$. ders, $40 \mathrm{dk}$. teneffüs uygulamasının temelinde yatan da aynı anlayıştır (Hürriyet, 25.03.2019). Akademik başarıda oyuncak ve oyunun ciddi katkısının olduğu görülmektedir.

\section{Sonuç ve Öneriler}

Modern eğitim anlayışı ciddi değiş̧imler göstermiş, sadece okullarla ve buradaki eğitimle sınırlı kalmamıştır. Örgün eğitimi destekleyecek oyun, oyuncak, oyuncak müzeleri ve farklı etkinlik alanları okul eğitiminin tamamlayıcısı pozisyonuna gelmişlerdir. Artık ilgi odağı olan, tarihi ve turizm açısından öne çıkan şehirler bu özelliklerine "çocuk dostu şehir" kavramının içini dolduracak müzeler, parklar ve diğer altyapılar katma yarışına girmişlerdir. Çocukların her türlü ihtiyacını karşılayabilen şehirler yaşanmaya değer şehirler olarak kabul edilmektedir. Bilindiği gibi eğitim süreci bir çevrede gerçekleşmekte, bu çevre okul ve yaşanılan bölgeden oluşmaktadır. Okuldaki ve çevredeki uyarıcıların çokluğu ve kalitesi başarıyı etkilemektedir. Sevgi çocuklar için ne kadar önemli ve vazgeçilmez ise, oyun, oyuncak ve bunların eğitsel olarak kullanılabileceği mekânlar da bir o kadar önemlidir. Eğitim problemini çözmüş ülkelerde okuldaki örgün eğitim kadar, dışarıdaki oyun ve oyuncaklarla meşgul olmanın ve bu etkinliğe yeterince zaman ayırmanın çocukların beden ve ruh sağlığına çok iyi geldiği, akademik başarılarını arttırdığı ortaya çıkmıştır. 
200 | M. ÖNDER / Oyun, Oyuncak ve Oyuncak Müzelerinin Çocuk Eğitiminde Aktif Olarak Kullanılması ve Başarıya Katkısı

Oyun ve oyuncak çocuk için yaşam zenginliği sağlar, bu durum onun öğrenmesini kolaylaştırır. Oyun esnasında çocuğun duyuları daha iyi ve yoğun çalışır. Merak, anlama, mantık yürütme becerileri gelişir. Yaratıcı düşüncenin gelişmesine katkı sağlar, dil gelişimine ciddi destek oluşturur. Örgün eğitimde gereken başarıyı elde edememekten şikâyet ediyoruz. Bunu düzeltmek için daha yoğun ders programları ve ek kurslar açarak çare arıyoruz. Belki de teneffüs ve oyun saatlerini arttırarak beklediğimiz başarıyı yakalayabiliriz. Çünkü çocuklar hareket halindeyken, oyun ve oyuncakla meşgulken beyinleri daha iyi çalışmaktadır. Ahlak ve değer eğitimi konusunda en ciddi fırsatlar oyunlardır. İstendik davranışların hayata yansıması bu davranışları sevdirerek öğretmeye bağlıdır.

Aslında oyun, oyuncak ve oyuncak müzeleri örgün eğitimin en önemli tamamlayıcı unsurudur. Ülkemizde halen faaliyette bulunan İstanbul, Ankara, İzmir, Antalya, Gaziantep, Samsun oyuncak müzelerinin yanı sıra; Ankara Çamlıdere Belediyesi Oyuncak Müzesi, Kapadokya Oyuncak Müzesi, Antalya Kepez Belediyesi Oyuncak Müzesi, Ankara ve Antalya Evrensel Değerler Oyuncak Müzeleri eğitim ağırlıklı işlevlerini sürdürmektedirler. Bu tür müzelerin çoğalması, okul çağındaki çocuklar için kolay ulaşılabilir mekânlar olması eğitimde kalite artışına katkı sağlamaktadır.

Eğitimin vazgeçilmez bileşeni olan oyuncak müzeleri sadece gezilecek mekânlar değildir. Bu mekânların içerisinde ve çevresinde yapılacak eğitsel faaliyetler asıl amaçtır. Oyuncak müzeleri bulundukları şehirlere çok önemli eğitsel, kültürel ve ekonomik katkı sağlayabilecektir. Federal Almanya'daki Nürnberg, Schwabach, Neustadt, Sonneberg, Fürth ve Donauwörth gibi şehirlerdeki oyuncak sanayii ve etrafındaki oyuncak tamircileri, oyuncak müzeleri ülke eğitimine, turizmine ve ekonomisine ciddi katkı sağlayan bir sektör haline gelmiştir. Ülkemizde her şehir, bölge ve ilçenin öne çımış bir markası, oyunu, oyuncağı veya ürünü bulunmaktadır. Bu gerçekten hareketle her yıl farklı bölgelerde belli tarihlerde temalı çocuk şenlikleri, festivalleri yapılabilir. Bu etkinliklerde çocuk oyunları, oyuncaklar öne çıkarılarak yarışmalar, eğitsel faaliyetler gerçekleştirilebilir. Başta eğitimciler olmak üzere çocuklar ve tüm kesimlerin katılması ile hem tanıtım hem de kaynaşma, tanışma, ekonomik girdi sağlanabilir. Sadece 
M. ÖNDER / Active Use of Games, Toys and Toy Museums in Children's Education and Their Contribution to Success | 201 tarihi eserlerimiz ile değil, oluşturacağımız yeni ilgi alanları ile rekabet edebiliriz. Bunların başında eğitim ve teknoloji gelmektedir. Eğitimde başarı çok yoğun ders programları ve ayrıntılı teoriler ile değil, çocukları mutlu ve motive edecek oyun, oyuncak, spor ve sanatsal etkinlikler gibi küçük ayrıntılarla ve uygulamalarla mümkündür. Eğitim faaliyetleri yaşanan hayatla iç içe olduğu zaman davranış haline gelmekte ve kalıcı olabilmektedir. Oyun, oyuncak ve oyuncak müzelerinin örgün eğitimde aktif olarak kullanılması başarıyı artırabilecektir.

\section{Kaynakça}

Adıgüzel, Ömer. "Oyun ile Matematik Öğretimi Olur mu?". Yurt Gazetesi, 17.01.2020.

Akgül, Esra. "Erken Çocukluk Döneminde Oyun”. Okul Öncesi Ĕ̆itimde Özel Öğretim Yöntemleri. ed. Serpil Pekdoğan. 1-19. Ankara: Eğiten Kitap Yayınları, 2016.

Akın, Sunay. Kırdı ̆̆ımız Oyuncaklar. İstanbul: İş Bankası Yayınları, 36. Basim, 2016.

Akın, Sunay. Hayal Kahramanları. İstanbul: İş Bankası Yayınları, 2015.

Aksoy, A. Belgin. Okul Öncesi Ĕ̆itimde Oyun. Ankara: Hedef Yayıncılık, 2015.

Aydın, Ayhan. Eğitim Psikolojisi. Ankara: Pegem Akademi Yayıncılık, 2011.

Aykaç, Murtaza - Köhce, Davut. Eğitsel Oyunlar ile Matematik Öğretimi. Ankara: Pegem Akademi Yayınları, 2020.

Bacanlı, Hasan. Eğitim Psikolojisi. Ankara: Pegem Akademi Yayıncılık, 2011.

Bakırcıoğlu, Rasim. Çocuk ve Ergende Ruh Sağlı̆̆ı. Ankara: Anı Yayıncılık, 2013.

Akıncı, Gülden. "Bavyera'da Oyuncaklar Arasında”. Skylife Dergisi 417 (2018), 126-132.

Balat, Gülden Uyanık. Okul Öncesinde Değerler Eğitimi ve Etkinlik Örnekleri. Ankara: Pegem Akademi Yayınları, 2012.

Bee, Helen - Boyd, Denise. Çocuk Gelişim Psikolojisi. İstanbul: Kaknüs Yayinları, 2009.

Berk, E. Laura. Çocuk Gelişimi. çev. Ali Dönmez. Ankara: İmge Yayınevi, 2013. 
202 | M. ÖNDER / Oyun, Oyuncak ve Oyuncak Müzelerinin Çocuk Eğitiminde Aktif Olarak Kullanılması ve Başarıya Katkısı

Bilgin, Beyza. İslam'da Çocuk. Ankara: Diyanet İşleri Başkanlığı Yayınları, 1987.

Comenius, J. Amos. Büyük Didaktika. çev. Hasip Aytuna. Ankara: MEB Yayınlar1, 1964.

Çakar, Firdevs Savi. "Illkokul Döneminde Uyum ve Davranış Problemleri". Yaşam Dönemleri ve Uyum Sorunları. 169-225. Ankara: Pegem Akademi Yayınları, 2017.

Dilci, Tuncay. Dijital Diyet Zamanı. Kayseri: Geçit Yayıncılık, 2016.

Doğru, S. Sunay Yıldırım vd.. Çocuk Hakları ve Koruma. Ankara: Eğiten Kitap Yayınları, 2017.

Erduran, Nurdan - Yılmaz, Mehmet. Oyun Dünyam Dünyam Oyun. Ankara: Eğiten Kitap Yayınları, 2016.

İbrahim H. Diken vd.. Erken Çocukluk Eğitimi. Ankara: Pegem Akademi Yayıncilık, 2012.

Elif Çelebi vd.. Erken Çocukluk Döneminde Yaratıcılık ve Geliştirilmesi. Ankara: Pegem Akademi Yayıncilık, 2014.

Göçeri, Nebahat. Montessori Metodunda Dini Eğitimin Yeri. Ankara: Son Çă̆ Yayınları, 2019.

Göka, Erol. İnternet ve Psikolojimiz. İstanbul: Kapı Yayıncılık, 2017.

Gür, Çağla. Çocuk Ĕ̆itiminde Önemli Noktalar. Ankara: Anı Yayıncılık, 2017.

Güven, Gülçin. “Okul Öncesi Eğitim Programında Kullanılan Yöntem ve Teknikler". Okul Öncesi Ĕ̆itimde Özel Öğretim Yöntemleri. ed. Fatma Alisinanoğlu. 67-109. Ankara: Pegem Akademi Yayınları, 2011.

Heinelt, Gottfried. "Psychologische Grundlegung der Entwicklung des Kindes im Vorschulealter". Religiöse Erziehung von Kleinkindern. (Hr. Joseph Sauer). çev. Mustafa Önder. 49-82. Tokat: Arı Ofset Basımevi, 2009.

Hürriyet Gazetesi, 25.03.2019 tarihli nüsha.

Karadeniz, Ceren - Artar, Müge. “Türkiye'de Oyuncak Müzelerinin

Durumu ve Sürdürülebilirliği”. Elektronik Sosyal Bilimler Dergisi 16/61 (2017), 477-492.

Koglin, Ute - Petermann, Franz. Verhaltenstraining im Kindergarten. Göttingen: Hogrefe Verlag, 2013. 
M. ÖNDER / Active Use of Games, Toys and Toy Museums in Children's Education and Their Contribution to Success | 203

Köylü, Mustafa - Oruç, Cemil. Çocukluk Dönemi Din Eğitimi. Ankara: Nobel Yayınevi, 2017.

Miller, H. Patricia. Gelişim Psikolojisi Kuramları. çev. Zeynep Gültekin. Ankara: İmge Kitabevi, 2008.

Mustafa Satı. Layihalarım. İstanbul: Matbaa-i Hayriye ve Şürekası, 1326.

Milliyet Gazetesi. 28 Mayıs 2015 tarihli nüsha.

Onur, Bekir. Oyuncaklı Dünya: Oyuncağın Toplumsal Tarihi. Ankara: İmge Kitabevi, 2010.

Onur, Bekir. Oyunlar ve Oyuncaklar. Ankara: Kalem Kitap Yayınları, 2016.

Ögel, Kültegin. İnternet Bağımlılı̆̆ı. İstanbul: İş Bankası Kültür Yayınları, 2012.

Önder, Mustafa. Türk Eğitim Tarihi. Ankara: Anı Yayıncılık, 3. Basım, 2014.

Önder, Mustafa. "Contribution of Plays and Toys to Children's Value Education". Asian Journal of Education and Training 4/2 (2018), 146149.

Özçapkın, Ceylan. “Çocuk Dostu Kentler”. Skylife Dergisi 429 (2019), 117128.

Özgül, Fatih - Kanak, Mehmet. Bir Dünya Oyun. Ankara: Sonçağ Yayınları, 2019.

Pehlivan, Hülya. Oyun ve Öğrenme. Ankara: Anı Yayıncılık, 2014.

Poyraz, Hatice. Okul Öncesinde Oyun ve Oyun Örnekleri. Ankara: Anı Yayıncilik, 2017.

Sahlberg, Pası. Eğitimde Finlandiya Modeli. İstanbul: Metropolis Yayıncılık, 2018.

Selçuk, Mualla. Çocuğun Eğitiminde Dini Motifler. Ankara: TDV Yayınları, 1991.

Sevinç, Müzeyyen. Erken Çocukluk Gelişimi ve Eğitiminde Oyun. İstanbul: Morpa Yayınları, 2009.

Stachel, Günther. "Religiöse Erziehung in Der Familie Von Heute". Religiöse Erziehung Von Kleinkindern. (Hr. Joseph Sauer). çev. Mustafa Önder. 36-46. Tokat: Arı Ofset Basımevi, 2009.

Şen, Müge. "Erken Çocukluk Eğitiminde Oyun ve Önemi". Erken Çocukluk Ĕ̆itimi. ed. İbrahim H. Diken. 404-428. Ankara: Pegem Akademi Yayınları, 2012. 
204 | M. ÖNDER / Oyun, Oyuncak ve Oyuncak Müzelerinin Çocuk Eğitiminde Aktif Olarak Kullanılması ve Başarıya Katkısı

Tepeli, Kezban. "Montessori Yaklaşımında Çocuğun Gelişimi ve Eğitimi". Okul Öncesi Eğitiminde Montessori Yaklaşımı, ed. E. Çakıroğlu Wilbrandt. 50-85. Ankara: Kök Yayıncılık, 2014.

Tolstoy, L. Nikolayeviç. İnsan Ne İle Yaşar?. çev. Murat Çiftkaya. İstanbul: Şule Yayınları, 2011.

Tuğrul, Belma. “Oyun Temelli Öğrenme”. Okul Öncesinde Özel Öğretim Yöntemleri. ed. Rengin Zembat. 177-204. Ankara: Anı Yayıncılık, 2012.

Varış, Fatma. Ĕ̆itimde Program Geliştirme. Ankara: A.Ü. Eğitim Fakültesi Yayınları, 1988.

Wilbrandt, E. Çakıroğlu. Maria Montessori Yöntemiyle Çocuk Eğitimi Sanatı. İstanbul: Sistem Yayıncilık, 2009.

Yalçınkaya, Tosun - Yalçınkaya, Ç. Demirhan. Oyuncaklar. İstanbul: Morpa Yayıncilik, 2011.

Yeşil, Adnan. Anadolu Pedagojisi. İstanbul: Çalıkuşu Yayınları, 2018.

Yörükoğlu, Atalay. Çocuk Ruh Sağlı̆̆ı. İstanbul: Özgür Yayınevi, 2008. 